\title{
DOSES INCOME SMOOTHING IMPROVE INFORMATIVENESS OF STOCK PRICES?
}

\author{
Shinta Ningtiyas Nazar \\ Universitas Pamulang \\ Indonesia \\ E-mail:ashyafanie@gmail.com
}

\begin{abstract}
The purpose of this research is to get empirical evidence from effect Income smoothing to Informativeness of Stock Prices in Indonesian Stock Exchange (IDX). Population from this research is take from companies that have been listing Index LQ 45 in IDX form 2003 until 2015. Income Smoothing is masured by Jones's Model which have been modified by Kothari et. all (2005). Informativeness of stock price using Zarowin and Tucker Model (2006) Future Earnings Response Coeficient, and the relations to earnings persistence, which is can been seen from relation from current earnings dan future earnings.

The research is using data from year 2003 until 2015 period, and year 2014 used as terminal year. That found income smoothing have a negative effect to informativeness of stock price and also found the managers' income smoothing action always decreases earnings from 2013 to 2015. Current earnings have related to future earnings.
\end{abstract}

Key Words : Pre-Discretionary Income; Future Earnings Response Coefficient; Earnings Persistence; Index LQ 45

\section{PENDAHULUAN}

Tindakan investasi di pasar modal di dunia terus mengalami perkembangan, hal ini secara nyata berdampak pada peningkatan kebutuhan akan ketersediaan informasi data akuntansi yang bersifat dapat diandalkan dan terpercaya. Pelaporan keuangan berdasarkan informasi data akuntansi digunakan oleh para investor, kreditor, dan pihak lainnya untuk menganalisis kinerja manajemen serta digunakan dalam pengambilan keputusan (Wolk, Dodd, \& Rozycki, 2008:3). Penggunaan informasi data akuntansi tidak hanya terbatas pada pengambilan keputusan internal, tetapi juga digunakan sebagai bentuk pertangungjawaban eksternal manajemen kepada pihak-pihak yang memiliki kepentingan terhadap perusahaan. Pelaporan keuangan merupakan refleksi kegiatan-kegiatan perusahaan, sehingga para manajer sebagai penyedia informasi akuntansi menggunakan laporan keuangan sebagai suatu bentuk komunikasi informasi yang berasal dari dalam perusahaan.

Proses pengambilan keputusan memerlukan nilai informasi yang dapat diandalkan dan terpercaya, sehingga menghasilkan keputusan optimal. Informasi bernilai adalah informasi yang memiliki kemampuan untuk meningkatkan pengetahuan dan keyakinan pemakai dalam mengambil keputusan. Pelaporan keuangan adalah pengkomunikasian informasi keuangan perusahaan kepada pengguna. Produk 
Jurnal Ilmiah Econosains

Vol. 15 No. 2 Agustus 2017
E-ISSN: 2252-8490

http://doi.org/10.21009/econosains.015.2.5 terpenting sistem pelaporan keuangan adalah laporan keuangan. Laporan keuangan memberikan informasi keadaan perusahaan dan menyajikan informasi sumber daya, klaim terhadap sumber daya dan perubahan-perubahannya (Suwardjono, 2005). Informasi yang disajikan laporan keuangan seharusnya berguna untuk kegiatan investasi, kredit dan memperkirakan arus kas, serta laba di masa depan.

Signalling Theory menjelaskan kemampuan sebuah perusahaan didalam menghasilkan capital dipengaruhi oleh reputasi perusahaan yang baik (Scott, 2000). Reputasi perusahaan tercermin pada laporan keuangannya. Pelaporan keuangan yang baik akan menurunkan cost of capital investasi, dan menyebabkan ketidakpastian perusahaan dan risiko investasi yang menurun (Botosan, 2005). Perusahaan dengan reputasi yang baik tercermin pada laba, jika laba yang dihasilkan kemudian direspon secara positif maka akan terjadi peningkatan pembelian saham perusahaan oleh para investor begitu juga sebailknya, sehingga harga saham sebuah emiten merefleksikan tingkat informasi tertentu dari dalam perusahaan (Watts dan Zimmerman, 1986: 37).

Konsep income smoothing menurut Fudenberg dan Tirole (1995) mengasumsikan bahwa investor adalah orang yang menolak risiko, sehingga laba perusahaan yang tidak normal atau tidak stabil, dianggap investor memiliki risiko pada saat melakukan investasi, dan mempengaruhi motivasi investor untuk berinvestasi pada perusahaan tersebut. Income smoothing menjadikan laba lebih tidak sesuai keadaannya, yaitu manajer dengan sengaja mendistorsi jumlah laba Zarowin \& Tucker (2006). Penelitian ini mengukur income smoothing berdasarkan model Kothari, dkk (2005) dengan menguji hubungan negatif antara perubahan discretionary-accruals proxy ( $\triangle \mathrm{DAP})$ dan perubahan pada prediscretionary income ( $\triangle \mathrm{PDI}$ ) semakin negatif korelasi yang terjadi maka semakin tinggi income smoothing perusahaan.

Pengaruh income smoothing pada informativeness of stock price dan alokasi sumber (resource allocation) di Indonesia telah diketahui, income smoothing menyebabkan informasi yang terkandung di dalam harga saham menjadi semakin informatif pada industri maufaktur Nazar (2010). Jan Scheimer (2015) menemukan jika data yang digunakan menggunakan jenis industri yang berbeda maka akan menyebabkan keinformativan harga saham yang berbeda. Hubungan antara income smoothing dan informativeness of stock price sangat penting bagi akademisi dan para pembuat kebijakan, hal ini berhubungan dengan pertanyaan yang sangat sering ditanyakan seberapa besar discretionary accounting (contoh: earnings management) yang seharusnya dilakukan oleh perusahaan, sehingga akuntansi di samping berhubungan erat dengan masalah pengukuran, juga berkaitan erat dengan masalah komunikasi, sehingga betapapun efektif proses pengukuran yang dilakukan dalam akuntansi, informasi yang dihasilkannya akan kurang bermanfaat jika tidak dikomunikasikan dengan tepat. Zarowin (2002) melakukan penelitian untuk menilai tingkat informasi apakah suatu saham melakukan income smoothing 
Jurnal Ilmiah Econosains

Vol. 15 No. 2 Agustus 2017
E-ISSN: 2252-8490

http://doi.org/10.21009/econosains.015.2.5 terefleksi pada harga saham menemukan pengaruh signifikan.

Subramanyam (1996) menemukan hubungan positif antara return dan discretionary accruals. Hunt, dkk (2000) melaporkan bahwa income smoothing meningkatkan informativeness of stock price dan laba masa depan, dengan melihat hubungan antara kenaikan harga saham dan laba. Penelitian ini fokus pada hubungan return dan informasi akuntasi masa depan, berdasarkan penelitian Collins, dkk (1994), dan Zarowin \& Tucker (2006) menunjukkan income smoothing menjadikan laba lebih informatif, sehingga return saat ini merefleksikan informasi laba masa depan, dan FERC menjadi lebih tinggi untuk perusahaan dengan income smoothing yang tinggi. Income smoothing meningkatkan informativeness of stock price, income smoothing juga memperkuat hubungan antara laba masa depan dan laba sekarang, juga meningkatkan persistensi laba (Zarowin \& Tucker, 2006).

Sloan (1996) tingkat akrual yang rendah berhubungan dengan persistensi yang lebih rendah dan investor tidak sepenuhnya mengantisipasi earning persistence (persistensi laba) yang lebih rendah, sehingga sering terjadi mispricing pada investasi. Income smoothing selain berpengaruh terhadap informativeness of stock price, juga berdampak pada persistensi laba. Persistensi laba menunjukkan tren laba cenderung stabil yang disebabkan oleh income smoothing, sehingga income smoothing memperkuat persistensi laba. Penelitian ini merefleksikan keuntungan yang diperoleh dari perilaku kebijakan akrual manajemen. Penelitian ini menguji pada hubungan antara income smoothing, informativeness of stock price, dan persistensi laba.

Koch (1981) menemukan bukti empiris bahwa income smoothing lebih banyak dilakukan oleh widely held company daripada closely held company. Indonesia memiliki Indeks LQ 45 sebagai kategori perusahaan widely held company, dan risiko lebih rendah dibandingkan non LQ 45 (Polakitan, 2015), tingkat pengembalian atas saham yang tinggi, sehingga transaksi atas saham perusahaan tersebut cukup tinggi, dengan transaksi yang cukup tinggi maka apakah para pembuat laporan keuangan menggunakan tindakan perataan laba untuk menarik minta investor. Harga saham saat ini mengandung informasi laba masa depan lebih informatif ketika manajemen melakukan tindakan Income smoothing sehingga di Indonesia laba menjadi salah satu informasi akuntansi yang digunakan untuk menentukan informasi jangka panjang atau memprediksi laba masa depan oleh investor Nazar (2010).

Informasi privat yang diketahui oleh perusahaan dapat mempengaruhi sensitivitas harga saham Bill B. Francis et.al (2011) sehingga informasi yang dimiliki oleh manajemen utama di perusahaan akan berpengaruh terhadap tingkat pergerakan harga saham, seiring dengan penelitian Jenie Bai et. Al (2015) menemukan bahwa pada saat ini pasar keuangan lebih informatif dalam jangka lima tahun terakhir, hal ini mendorong terciptanya efisiensi ekonomi dan peningkatan nilai pada sektor keuangan. Income smoothing merupakan salah satu 
Jurnal Ilmiah Econosains

Vol. 15 No. 2 Agustus 2017
E-ISSN: 2252-8490

http://doi.org/10.21009/econosains.015.2.5 informasi privat yang hanya diketahui oleh manajemen utama,, pada industri manufaktur laba merupakan salah satu informasi yang digunakan oleh para investor sehingga sensitivitas pergerakan harga saham dipengaruhi oleh informasi yang dihasilkan oleh manajemen. Jenis industri yang berbeda akan dijadikan populasi dalam penelitian ini berdasarkan penelitian Jan Sceneemeier (2015). Kusumaningrostati (2014) menemukan bahwa harga saham tidak berpengaruh terhadap income smoothing pada industri perbankan, seiiring dengan Zuhriya (2015) juga tidak menemukan pengaruh risiko saham pada perataan laba industri consumer goods di Indonesia. Indeks LQ 45 terdiri dari berbagai industri di Indonesia, sehingga penelitian ini menguji pada hubungan antara income smoothing terhadap informativeness of stock price pada perusahaan LQ 45 Bursa Efek Indonesia.

\section{KAJIAN TEORI}

\section{a. Income Smoothing}

Ikatan Akuntan Indonesia (2013) mendefenisikan Income (penghasilan) sebagai kenaikan manfaat ekonomi selama suatu periode akuntansi dalam bentuk pemasukan atau penambahan aset atau penurunan kewajiban yang mengakibatkan kenaikan ekuitas yang tidak berasal dari kontribusi penanam modal. Income smoothing dianggap sebagai upaya yang dilakukan dengan sengaja untuk menormalkan laba dalam mencapai kecenderungan tingkat laba yang diinginkan (Bekaoui \& Riahi, 2013:56). Subramanyam (2013:87) pada Financial Statement Analysis, mendefenisikan perataan laba sebagai :
"Income smoothing is a common from of earnings management. Under this strategy, managers decrease or increase reported income so as to reduce it's volatility".

Manajer perusahaan memiliki motivasi untuk melakukan income smoothing, dengan asumsi stabilitas laba dan kenaikan tingkat pertumbuhan laba akan menjadi pilihan dibandingkan laba dengan rata-rata yang besar dengan variabilitas yang lebih besar (Bekaoui, 2013:56). Laba yang tidak stabil akan meingkatkan risiko investasi, dengan meingkatkan ketidakpastian jumlah laba, dan risiko investasi. Zarowin (2002) mendefenisikan income smoothing sebagai kebijakan akrual manajemen untuk menghilangkan variasi dialam aliran kas operasi, seperti variasi waktu dialam pelaporan laba yang diberikan oleh aliran kas operasi. Beberapa penelitian yang dilakukan di Indonesia pada umumnya menggunakan Indeks Eckel untuk menghitung tingkat income smoothing yang terjadi, tetapi pada penelitian Mawarti (2007) menguji pengaruh income smoothing terhadap Earnings Response Coefficient (ERC) di Indonesia, menunjukkan bahwa perhitungan income smoothing menggunakan Indeks Eckel tidak dapat menangkap adanya hubungan tersebut, sehingga peneliti menggunakan pengukuran income smoothing berdasarkan peneltian Zarowin \& Tucker (2006) dengan model yang telah digunakan Kothari, dkk (2005) yaitu; mengukur income smoothing menggunakan korelasi negatif antara perubahan discretionary accruals 
Jurnal Ilmiah Econosains

Vol. 15 No. 2 Agustus 2017
E-ISSN: 2252-8490

http://doi.org/10.21009/econosains.015.2.5 menggunakan proksi ( $\triangle \mathrm{DAP})$ dan perubahan pre-discretionary income $(\triangle \mathrm{PDI})$. Semakin tinggi perataan laba dibuktikan dengan semakin negatif korelasi antara $\triangle \mathrm{DAP}$ dan $\triangle \mathrm{PDI}$.

\section{b. Informativeness of Stock Price}

$\begin{array}{rlr}\text { Informasi } & \text { akuntansi sangat } \\ \text { berguna bagi } & \text { investor didalam }\end{array}$ mengestimasi nilai yang diharapkan dan risko dari surat berharga, sehingga pada dasarnya informasi mempengaruhi investor didalam menentukan kepercayaan dan tindakan yang akan dilakukan. Tingkat kegunaan informasi yang ada dapat diukur dengan perubahan harga saham (Scott, 2000;139). Nilai dari tingkat kegunaan informasi tersebut disebut sebagai information perspective on financial reporting, (Scott, 2000;140) mendefenisikan:

"The information perspective on financial reporting is an approach that recognizes individual responsibility for predicting future firm performance and that concentrates on providing useful information for this purpose. The approach recognizes that the market will react to useful information from any source, including financial statements".

Berdasarkan defenisi diatas maka informasi yang disajikan pelaporan keuangan memiliki pengaruh terhadap respon investor, yang tercermin pada perubahan harga saham.

Beberapa kegunaan informasi bagi para pelaku ekonomi didalam mengestimasi laba (Jones, 2007:418); laba yang dilaporkan oleh manajer dapat mempengaruhi harga saham, satu laba kejutan cenderung akan menjadi unggul diantara yang lain, saham dengan signifikansi revisi $5 \%$ atau lebih ke atas atau bawah sering menunjukkan nilai kinerja dibawah rata-rata, para investor yang tertarik membeli saham melaporkan berita buruk, sehingga harga saham jatuh kemudian membeli kembali, dan beberapa investor dapat memiliki akses pada laba yang dilaporkan dan berbagai kejutan yang timbul dari hal tersebut.

Zarowin \& Gelb (2002) informativeness of stock price adalah hubungan antara return saham saat ini dan perubahan laba masa depan, harga saham yang semakin informatif mengandung laba masa depan yang semakin besar, untuk mengukur hubungan ini. Zarowin \& Gelb (2002) meregresikan return saat ini dan perubahan laba masa lalu, saat ini dan masa depan, koefisien perubahan laba masa depan merupakan ukuran keinformatifan harga saham disebut sebagai Future Earnings Response Coefficient (FERC).

\section{c. Future Earnings Response Coefficient (FERC)}

Earnings response coefficient (ERC) didefenisikan Scott, (2000;152) sebagai berikut:

"An earnings response coefficient measures the extent of a security's abnormal market return in response to the unexpected component of reported earnings of the firm issuing that security".

Ada beberapa hal yang menyebabkan respon pasar yang berbedabeda terhadap laba, yaitu adalah persistensi laba, beta, struktur permodalan perusahaan, kualitas laba, growth opportunities, dan informativeness of price ( keinformatifan harga ) (Scott, 
Jurnal Ilmiah Econosains

Vol. 15 No. 2 Agustus 2017
E-ISSN: 2252-8490

http://doi.org/10.21009/econosains.015.2.5
2000). Pada penelitian ini menggunakan future earnings response coefficient (FERC), sebagai nilai ERC yang terjadi ditahun yang akan datang. Nilai FERC diprediksi lebih tinggi jika laba perusahaan lebih persisten di masa depan.

Zarowin \& Tucker (2006) kualitas laba yang semakin baik, maka memprediksi nilai FERC semakin tinggi, investor menilai laba sekarang untuk memprediksi laba dan return di masa yang akan datang. Faktor yang mempengaruhi respon pasar terhadap laba adalah keinformatifan dari harga pasar itu sendiri, semakin tinggi keinformatifan harga saham, maka kandungan informasi dari laba akuntansi semakin bertambah, oleh karena itu, FERC akan semakin rendah jika keinformatifan harga saham menurun Collins et,al (1994). Zarowin \& Tucker (2006), semakin informatif suatu harga saham maka hal ini juga akan menaikan persistensi laba, sehingga penelitian ini selain menilai keinformatifan harga saham melalui Future Earnings Response Coefficient (FERC) juga melihat pada persistensi laba.

\section{d. Earnings Persistence}

Subramanyam (2007:574), mendefenisikan persistensi laba sebagai:

"Earnings persistence is broadly defined to include the stability, predictability, variability, and trend in earnings".

\footnotetext{
Subramanyam (2013) menjelaskan bahwa praktek manajemen laba merupakan faktor yang mempengaruhi persistensi laba. Manajemen laba dan income smothing dapat memberikan dampak berupa lebih stabilnya dan dapat
}

diprediksi laba dibandingkan masa saat ini. Kecenderungan yang sering terjadi didalam penggunaan manajemen laba adalah manajer perusahaan melakukan tindakan penghilangan kegiatan yang menyebabkan distorsi dan keanehan pada hasil kegiatan operasi, sehingga akan menggangu stabilitas laba (Subramanyam, 2013:574).

\section{METODE PENELITIAN}

\section{a. Jenis Penelitian}

Penelitian ini digolongkan kedalam penelitian kausalitas, penelitian ini melakukan percobaan dalam memprediksi pengaruh dari satu 230able230ti dengan 230able230ti lainnya (Cooper and Schindler, 2012; 144), kemudian uraian yang mengungkapkan besar atau kecilnya suatu pengaruh atau hubungan antar 230able230ti yang dinyatakan dalam angka-angka. Penelitian ini menguji pengaruh perataan laba terhadap keinformatifan harga saham.

\section{b. Objek Penelitian}

Jenis data pada penelitian ini termasuk kedalam jenis data 230able230tic230, berupa jenis data penelitian yang antara lain berupa laporan program (Indriantoro dan Supomo, 2013:146). Data sekunder merupakan sumber data yang diperoleh secara tidak langsung melalui media perantara yaitu, data olahan yang berasal dari Indonesia Capital Market Directory yang diterbitkan oleh Institute for Economic and Finance Research (ECFIN) tahun 2010-2015 untuk mendapatkan data Net Income, dan Sales, sedangkan data EPS, Accrual, Property Plant Equipment (PPE) dan Return on Assets (ROA), return 
Jurnal Ilmiah Econosains

Vol. 15 No. 2 Agustus 2017

saham tahun 2012, 2013, 2014, dan 2015 diperoleh dari Thomas Reuters.

\section{c. Instrumen pengumpulan Data}

Populasi adalah total kumpulan elemen yang digunakan untuk menguji suatu hipotesis kemudian diambil beberapa kesimpulan (Cooper and Schindler, 2012; 374). Populasi cenderung pada penentuan jumlah sumber data yang mempunyai kualitas dan karakteristik tertentu (Nawawi, 2015:141). Penelitian ini mengunakan populasi perusahaan-perusahaan yang terdaftar pada Indeks LQ 45 (go public) di Bursa Efek Indonesia (BEI) sejak tahun 2003 hingga 2016 sebagaimana tercantum pada www.idx.go.id.

Teknik pemilihan sampel pada penelitian ini adalah Nonprobability Sampling, dengan metode yang digunakan adalah pemilihan sampel bertujuan berdasarkan judgement (purposive sampling). Sampel ditentukan berdasarkan keputusan subjektif peneliti yang didasarkan pada pertimbangan atau kriteria tertentu (Cooper and Schindler, 2012; 397). Pada cara ini peneliti mulamula mengidentifikasi semua karakteristik populasi yang hendak diteliti dan mempelajari karakteristik tersebut, kemudian menetapkan sampel berdasarkan pertimbangan sendiri. Populasi yang digunakan adalah emiten yang tetap terdaftar sebagai perusahaan yang terdaftar di LQ 45 di BEI 2003 2016 tercatat sebanyak 131 emiten.

\section{d. Analisis Data}

Pengujian hipotesis

mengemukakan uji regresi untuk seluruh sampel dalam penelitian ini. Pegujian ini dilakukan untuk melihat pengaruh income
E-ISSN: 2252-8490

http://doi.org/10.21009/econosains.015.2.5

smoothing terhadap keinformatifan harga saham, pengujian ini menggunakan persamaan:

$\mathrm{R} 14=\mathrm{a}+$ b0EPS13 + b1EPS14 + b2EPS15 + b3rR15 + b4IS + b5IS*EPS13

$\begin{array}{cc}+ & \text { b6IS*EPS14 } \\ \text { b7IS*EPS15 }+\grave{\varepsilon} & +\end{array}$

Dimana;

R14 = Return 2014

EPS13 = Earnings per Share 2013

EPS14 = Earnings per Share 2014

EPS15 = Earnings per Share 2015

R15 = Return 2015

IS = Income Smoothing

Hasil pengujian 231able231tic pada model hipotesis (Ha1) akan memiki pengaruh jika (IS*E15) memiliki tanda (+) dan signifikan secara 231able231tic, jika hal tersebut tidak memenuhi maka berlaku hubungan (Ho1).

Pengujian hipotesis mengemukakan uji regresi untuk seluruh sampel dalam penelitian ini. Pegujian ini dilakukan untuk melihat pengaruh income smoothing terhadap peristensi laba, pengujian ini menggunakan persamaan:

EPS15 $=\mathrm{a}+\mathrm{b} 0$ EPS13 + b1IS +

b2IS*EPS13 $+\grave{\varepsilon}$

Dengan:

EPS15 = Earnings Per Share 2015

EPS13 = Earnings Per Share 2013

IS = Income Smoothing

Hasil pengujian 231able231tic pada model hipotesis (Ha2) akan memiki pengaruh positif, jika (IS*EPS13) memiliki tanda $(+)$ dan signifikan secara 231able231tic, sehingga IS memperkuat hubungan antara laba saat ini dan laba masa depan, , jika hal tersebut tidak 
Jurnal Ilmiah Econosains

Vol. 15 No. 2 Agustus 2017
E-ISSN: 2252-8490

http://doi.org/10.21009/econosains.015.2.5 memenuhi maka berlaku hubungan (Ho2).

\section{HASIL DAN PEMBAHASAN}

Pemilihan sampel pada penelitian ini dimulai dari pemilihan populasi, yang dilanjutkan dengan memberikan kriteriakriteria penelitian terhadap populasi tersebut sehingga diperoleh sekumpulan sampel, dengan penjelasan sebagai berikut:

a. Populasi pada penelitian ini adalah semua emiten yang dikategorikan sebagai Indeks LQ 45 di Bursa Efek Indonesia dari tahun 2003 sampai 2016 di www.idx.co.id. b. Perusahaan tersebut tidak pernah keluar dari Bursa Efek Indonesia.

c. Perusahaan tersebut memiliki kelengkapan data keuangan berupa Net Income, Sales, EPS, Accrual, $P P E, R O A$, dan return sejak Januari 2011-Desember 2015.

Teknik pemilihan sampel adalah judgement sampling dan kriteria pemilihan sampel mengikuti beberapa tahap seperti disajikan pada 232able berikut:

Tabel 1.1

Tabel Kriteria Pemilihan Sampel

\begin{tabular}{|c|c|}
\hline Kriteria Sampel & Perusahaan \\
\hline $\begin{array}{l}\text { Emiten yang terdaftar pada Indeks LQ 45 } \\
\text { sejak tahun 2003 hingga 2015 }\end{array}$ \\
\hline $\begin{array}{l}\text { Perusahaan tersebut telah delisting dari Bursa } \\
\text { Efek Indonesia sampai tahun 2015 }\end{array}$ \\
\hline $\begin{array}{l}\text { Perusahaan tersebut tidak memiliki } \\
\text { kelengkapan data keuangan berupa Net } \\
\text { Income, Sales, EPS, Accrual, PPE, ROA, dan } \\
\text { return sejak Januari 2012-Desember 2015 }\end{array}$ \\
\hline Total Sampel & $\mathbf{7 0}$ \\
\hline
\end{tabular}

Tabel 1.2

Hasil Pengujian Signifikansi, Autokorelasi, dan Heterokedastisitas

Hipotesis a1

\begin{tabular}{lllll}
\hline Variabel & t-statistics & sig. & VIF & sig. AbsUt \\
\hline Return 2014 (R14) & 0,002 & 0,998 & & \\
Earning 2013 (E13) & 0,064 & 0,950 & 2,228 & 0,892 \\
Earning 2014 (E14) & 2,048 & 0,046 & 2,060 & 0,819 \\
Earning 2015 (E15) & $-0,974$ & 0,335 & 4,127 & 0,164 \\
Return 2015 (R15) & 40,407 & 0,000 & 3,164 & 0,977 \\
Income Smoothing (IS) & $-1,503$ & 0,298 & 4,438 & 0,424 \\
ISE13 & 1,437 & 0,158 & 3,455 & 0,366 \\
ISE14 & $-0,599$ & 0,552 & 3,957 & 0,653 \\
ISE15 & 0,289 & 0,787 & 4,750 & 0,452 \\
\hline
\end{tabular}




\begin{tabular}{l}
\hline Durbin-Watson 1,948 \\
\hline Sumber : Hasil SPSS ver 17 \\
\end{tabular}

Uji Signifikansi Future Earnings Response Coefficient (FERC), Pengujian terhadap hipotesis a1 menyatakan bahwa income smoothing berpengaruh positif terhadap Future Earnings Response Coefficient, dapat dilihat pada tabel 1.2. Pengujian ini menggunakan model regresi, dimana variabel independen di moderasi oleh income smoothing, untuk meperkuat hubungan antara variabel independen dan dependen. Tabel 1.2 menunjukkan ISE15 (t-statistik =0,289, sig $=0,787)$ bernilai positif dan tidak signifikan hal ini menunjukkan bahwa Income smoothing bukan faktor yang mempengaruhi keinformatifan harga saham yang direfleksikan terhadap FERC, mengindikasikan total informasi laba masa depan tidak tercermin pada harga saham saat ini, hal ini berbeda dengan penelitian sebelumnya Nazar (2010) Income smoothing mempengaruhi keinformatifan harga saham pada industri manufaktur. Hubungan positif antar variabel menjelaskan bahwa kenaikan harga saham akan meningkatkan FERC, tetapi bukan income smoohing yang memoderasinya. Peneliti di Indonesia telah meneliti mengenai pengaruh perataan laba, beberapa diantaranya tidak menemukan pengaruh income smoothing baik terhadap return saham dan harga saham (Salno dan Baridwan, 2000), Suwito dan Herawaty (2005), Juniarti (2005), Mawarti (2007), Andry Algrey (2013), Kusumaningrostati (2014) dan Zuhriya (2015). Hal ini disebabkan pada industri yang berbeda menemukan hasil yang berbeda terhadap keinformatifan harga saham, seiiring dengan penelitian
(Jan Schneemeier, 2015) karakteristik perusahaan yang berbeda akan menimbulkan tingkat keinformatifan yang berbeda Indeks LQ 45 terdiri dari jenis industri yang beragam sehinggan tingkat keinformatifan harganya juga berbeda, sehingga nilai yang tidak signifikan dapat disimpulkan dari jenis perusahaan yang berbeda, disebbakan setiap karakteristik perusahaan memiliki respon tersendiri terhadap keinformatifan harga saham.

Koefisien laba masa lalu (EPS13) memiliki (t-statistik $=0,064$, sig=0,950) mengindikasikan bahwa laba masa lalu memiliki pengaruh positif terhadap return saat ini tetapi bukan faktor utama, setelah dimoderasi oleh income smoothing ISE13 (t-statistik=1,437, sig=0,158) laba tahun lalu memiliki pengaruh positif terhadap return saat ini tetapi tidak signifikan. Nainggolan (2015) menemukan bahwa laba tahun lalu mempengaruhi harga saham sebesar $26 \%$, $74 \%$ lainnya dipengaruhi oleh faktor lain seperti tingkat suku bunga, indeks harga saham gabungan, news and rumors, sehingga pada penelitian ini menemukan hal yang sama bahwa laba saat ini bukan merupakan faktor utama yang mempengaruhi harga saham. Investor di Indonesia lebih cenderung menggunakan analisis teknikal disbanding fundamental.

Koefisien laba saat ini FERC (EPS14) (t-statistik=2,048, $\quad$ sig=0,046) mengindikasikan bahwa laba saat ini memiliki pengaruh terhadap return saat ini dan signifikan hal ini menunjukkan bahwa investor mengambil keputusan investasinya menggunakan data EPS tahun berjalan dibandingkan laba tahun 
Jurnal Ilmiah Econosains

Vol. 15 No. 2 Agustus 2017
E-ISSN: 2252-8490

http://doi.org/10.21009/econosains.015.2.5

sebelumnya, koefisien laba saat ini setelah dimoderasi oleh income smoothing ISE14 (t-statistik = -0,599, sig $=0,552)$, memiliki pengaruh negatif dan tidak signifikan di BEI, hal ini sesuai dengan penelitian yang dilakukan oleh Mawarti (2007) tidak menemukan pengaruh income smoothing dengan ERC, dikarenakan perusahaan yang melakukan income smoothing dinilai negatif sehingga pasar tidak bereaksi atas informasi yang diberikan. Hal ini semakin memperkuat penelitian bahwa investor di Indonesia lebih cenderung menggunakan informasi masa kini untuk pertimabangan investasinya dalam memilih salam terutama pada indeks LQ 45, sehingga sesuai dengan penelitian Polakitan (2015).

Return masa depan (R15) sebagai variabel kontrol (t-statistik $=40,407$, sig $=0,000)$ memiliki pengaruh positif dan signifikan, hal ini mengindikasikan bahwa return saham saat ini berpengaruh secara positif terhadap return masa depan. Hal ini mengindikasikan bahwa investor menggunakan pertimbangan return saat ini untuk menetukan return masa depan, sehingga harga saham mencerminkan

Tabel 1.3

Hasil Pengujian Signifikansi, Autokorelasi, dan Heterokedastisitas Hipotesis a2

\begin{tabular}{lllll}
\hline Variabel & t-statistics & sig. & VIF & sig. Abs Ut \\
\hline Earning per Share 2015 (EPS 15) & 5,264 & 0,000 & & 0,000 \\
Earning per Share 2013 (EPS 13) & $-1,339$ & 0,185 & 2,601 & 0,783 \\
Income Smoothing (IS) & 11,7 & 0,000 & 1,003 & 0,305 \\
ISE13 & 1,418 & 0,161 & 2,605 & 0,890 \\
\hline Durbin-Watson & 2,033 & & &
\end{tabular}

Sumber : Hasil SPSS ver 17

nilai perusahaan saat ini. Seiiring dengan penelitian Jennie Bai (2015).

Koefisien laba masa depan FERC (EPS15) (t-statistik=-0,974, sig=0,335) memiliki pengaruh negatif terhadap return saham saat ini dan tidak signifikan, hal ini mengindikasikan return saat ini tidak memberikan pengaruh terhadap earning masa depan perusahaan, hasil pengolahan statistik variabel ini mengindikasikan bahwa investor didalam memprediksi earning masa depan emiten tidak hanya dapat menggunakan faktor return saat ini sebagai pertimbangan. E15 dimoderasi income smoothing (ISE15) (tstatistik=0,289, sig=0,787) hasilnya berubah menjadi positif tidak signifikan, pengolahan data ini mengindikasikan earning masa depan setelah dimoderasi income smoothing tidak memperkuat hubungan antara return saat ini dan earning masa depan, hal ini mengindikasikan bahwa investor di Indonesia dalam melakukan aktivitas investasinya lebih banyak menggunakan analisis teknikal dibandingkan fundamental perusahaan, dan menginginkan keuntungan jangka pendek.

\footnotetext{
Uji Signifikansi Earnings Persistence
(EP) Pengujian terhadap hipotesis a2

Uji Signifikansi Earnings Persistence
(EP) Pengujian terhadap hipotesis a2
}

menyatakan bahwa income smoothing berpengaruh positif signifikan terhadap 
Jurnal Ilmiah Econosains

Vol. 15 No. 2 Agustus 2017
E-ISSN: 2252-8490

http://doi.org/10.21009/econosains.015.2.5
Earnings Persistence ,IS (t-statistik=11,7, sig $=0,000$ ) dapat dilihat pada tabel 1.3. hal ini menggambarkan bahwa salah satu faktor yang menyebabkan persistensi laba adalah tindakan perataan laba, hal ini menguatkan Subramanyam (2013) menjelaskan bahwa tindakan manajemen laba adalah salah satu faktor yang menyebabkan persistensi laba. Tindakan income smoothing yang dilakukan lebih cenderung pada tindakan meningkatkan jumlah laba (increase) dibandingkan menurunkan jumlah laba emiten pada laba masa depan perusahaan.

Tabel 1.3 menunjukkan EPS13 (tstatistik=-1,339, sig=0,185) bernilai negatif dan tidak signifikan hal ini mengambarkan bahwa laba masa lalu tidak mempengaruhi perisitensi laba. ISE13 bernilai positif tidak signifikan (tstatistik $=\quad 1,418, \quad$ sig=0,161), mengindikasikan income smoothing berpengaruh positif tetapi bukan faktor utama pada peristensi laba. Mulyani (2003) menemukan bahwa persistensi laba tidak dipengaruhi oleh koefisien perubahan laba, dengan tambahan bahwa hubungan ini dapat terjadi jika tren pertumbuhan laba meningkat. Pada tahun 2015 terjadi penurunan laba akibat melemahnya nilai tukar Rupiah, meningkatnya suku bunga, dan pelaksanaan pemilu legislatif. Pernyataan ini diperkuat oleh penelitian (Easton dan Zimijweski, 1989) bahwa semakin permanen pertumbuhan laba dari waktu ke waktu maka akan semakin tinggi koefisien laba karena kondisi ini menunjukkan bahwa laba yang diperoleh perusahaan meningkat terus menerus. Sehingga jika tidak terjadi pertumbuhan laba maka tidak akan mempengaruhi persistensi laba.

\section{KESIMPULAN}

Berdasarkan hasil pengujian maka simpulan yang dapat diambil dari penelitian ini adalah:

1. Return saham saat ini tidak mengandung informasi laba masa depan lebih informatif ketika manajemen melakukan tindakan Income Smothing. Tindakan manajemen perusahan earnings management yang dilakukan dengan income smoothing tidak berpengaruh terhadap koefisien laba masa depan (future earnings response coefficient) perusahaan yang direfleksikan oleh return saham emiten saat ini, sehingga kecendrungan yang terjadi di Indonesia adalah laba tidak menjadi salah satu informasi akuntansi yang digunakan untuk menentukan investasi jangka panjang atau memprediksi laba masa depan oleh para investor.

2. Return saham saat ini akan mempengaruhi oleh return masa depan dan laba saat ini, hal ini sangat berkaitan dengan kandungan informasi atas laba yang dilakukan. Hal ini menggambarkan bahwa investor di Indonesia lebih cenerung menggunakan analisis teknikal dibandingkan fundamental, dilihat dari preferensi informasi menggunakan return dan laba saat ini, serta kecenderungan investasi adalah investasi jangka pendek, disebabkan tidak mempengaruhi laba masa depan, 
Jurnal Ilmiah Econosains

Vol. 15 No. 2 Agustus 2017
E-ISSN: 2252-8490

http://doi.org/10.21009/econosains.015.2.5 sehinggan hal ini dapat menjadi salah satu indikator mengenai inklusi keuangan Indonesia.

3. Tindakan income smoothing berpengaruh terhadap laba masa depan persistensi laba (earnings persistence) hal ini semakin memperkuat Subramayam (2013) bahwa manajemen laba adalah salah satu faktor yang menyebabkan persistensi laba. Laba saat ini dan dan laba saat ini setelah dimoderasi oleh income smoothing tidak memiliki pengaruh terhadap persistensi laba hal ini diebabkan terjadinya penurunan laba sebesar $13 \%$ pada tahun 2015, sementara laba yang persisten adalah laba yang memiliki kecendrungan nilai yang selalu naik, sehingga penurunan nilai ini menjelaskan mengapa laba masa lalu tidak berpengaruh terhadap persistensi laba.

\section{DAFTAR PUSTAKA}

Alergy, A. 2013. Pengaruh profitabilitas, financial leverage, dan harga saham terhadap praktek perataan laba pada perusahaan manufaktur yang terdapat pada Bursa Efek Indonesia. The Accounting Review. Vol. 51(1):110-122

Bai Jennie (2015) Have Financial Markets Become More Informative? Working Paper http://SSRN.com, diakses pada tanggal 17 Februari 2010.

Barnea, A. Joshua, R. and Simcha, S. 1976. Classificatory Smoothing of Income with Exstraordinary Items. The Accounting Review. Vol. 51(1):110-122
Beaver, et,al. 1983. How Well Does Replacement Cost Income Explain Stock Return. The Accounting Review. Vol. 39(2):26-30+39.

Bekaoui., Riahi, 2013, Teori Akuntansi, Jakarta: Salemba Empat.

Bidleman., C. 1973. Income Smoothing : The Role of Management, The Accounting Review. Vol.48 (4):653-67.

Bill B. Francis et al., C. 2011. Cross-listing, Price Informativeness and the sensitivity of Investment to stock price: The Role of Management, The Accounting Review. Vol.48 (4):653-67.

Botosan., Christine. A., 2005. Evidence That Greater Disclosure Lowers The Cost of Equity Capital, Corporate Governance at The Crossroads, New York: McGraw Hill.

Chen, Changling,. 2004. Earning Persistence and Stock Price Under-and Overreactions", University of WinconsinMadison, Working Paper http://SSRN.com, diakses pada tanggal 17 Februari 2010.

Cooper., \& Schindler. 2012. Business research Methods, Tenth Edition, NewYork: McGraw Hill.

Fudenberg, D., and J. Tirole, 1995. A Theory of Income and Dividend Smoothing Based on Incumbency Rents. Journal of Political Economy. Vol.103 (1):75-9.

Ghozali, I, 2009. Aplikasi Analisis Multivariate dengan Program SPSS, 
Jurnal Ilmiah Econosains

Vol. 15 No. 2 Agustus 2017

Semarang: Badan Penerbit Universitas Diponegoro.

Gordon, M. J, 1964. Postulates, Principles, and Research in Accounting. The Accounting Review. Vol.39 (2):251-263

Gujarati, Damodar., 2004. Basic Ecometrics, Fourth edition, New York: McGraw Hill.

Hartono, Jogiyanto., 2013, Teori Portofolio dan Analisis Investasi, edisi kelima, Yogyakarta: BPFE Yogyakarta.

Hunt, A., S. Moyer., T. Shevlin.. 2000. Earning Volatility, Earning Management, and Equity Value. University of Washington, Working Paper, http:ssrn.com, diakses tanggal 16 April 2010.

Ikatan Akuntan Indonesia. 2013. Standar Akuntansi Keuangan, Jakarta:Salemba Empat.

Indriantoro, Nur., dan B, Supomo.. 2013. Metodelogi Penelitian Bisnis untuk Akuntansi dan Manajemen, edisi pertama, Yogyakarta:BPFE Yogyakarta.

Institute for Economic \& Financial Research. 2006. Indonesian Capital Market Dictionary 2006. Jakarta: Jakarta Stock Exchange.

Jones, P.Charles.. 2007. Investement, Tenth Edition, Danver: Willey Publishers.

Juniarti., 2005. Analisa Faktor-Faktor Yang Berpengaruh Terhadap Perataan Laba
E-ISSN: 2252-8490

http://doi.org/10.21009/econosains.015.2.5

(Income Smoothing) Pada PerusahaanPerusahaan Go Public, Univ. Kristen

Petra, Jurnal Akuntansi dan Keuangan, Vol 7 No. 22005.

Kothari, S. P., A. Leone., and C, Wasley. 2005. Performance Matched Discretionary Accruals. Journals of Accounting and Economics. Vol.39(1):161 197.

Kusumaningrostati 2014. Analisis pengaruh faktor-faktor terhadap Income smoothing dan gender sebagai variabel moderator pada emiten perbankan. Accounting Review. July.2014

Juniarti., 2005. Analisa Faktor-Faktor Yang Berpengaruh Terhadap Perataan Laba (Income Smoothing) Pada PerusahaanPerusahaan Go Public, Univ. Kristen

Petra, Jurnal Akuntansi dan Keuangan, Vol 7 No. 22005.

Mawarti, Yuliana. 2007. Pengaruh Income Smoothing (Perataan Laba) terhadap Earnings Response Coefficient (Reaksi Pasar) pada Perusahaan Manufaktur Bursa Efek Jakarta (BEJ). Skripsi Universitas Negri Semarang.

Mursalim., 2003. Analisis Persepsi Dimensi Income Smoothing Terhadap Motivasi Investor Untuk Berinvestasi Pada Perusahaan Yang Terdaftar Di BEJ (Studipada Investor di Jateng dan DIY)”. Seminar Nasional Akuntansi VIII Solo. KAKPM 10:190-206. 
Jurnal Ilmiah Econosains

Vol. 15 No. 2 Agustus 2017
E-ISSN: 2252-8490

http://doi.org/10.21009/econosains.015.2.5
Nawawi, Prof. Dr. H. Hadari., 2015, Metode Penelitian Bidang Sosial. Cetakan kesepuluh. Yogyakarta:Gadjah Mada University Press.

Penman, S. H., X. J. Zhang.. 2002. Modeling Sustainable Earnings and P/E Ratios with Financial Statement Analysis. Columbia University, working paper http;ssrn.com, diakses pada tanggal 14 Februari 2010

Polakitan.. 2015. Analisis komparasi risiko saham LQ 45 dan Non LQ 45 pada beberapa sub sektor perusahaan yang terdaftar di Bursa Efek Indonesia.

". Seminar Nasional Akuntansi VIII Solo. K-AKPM 10:190-206.

Qi Chen, Ita Goldstein. 2011. Price Informativeness and Investment Sensitivity to Stock Price, working paper http; ssrn.com, diakses pada tanggal 14 Februari 2010

Schipper, K., 1989. Earnings Management. Accounting Horizon Vol. 3:91-106

Scott. R. William. 2000. Financial Accounting Theory, Second Edition, Ontario: Prentice Hall Canada Inc.

Sloan, Richard G. 1996. Do Stock Prices Fully Reflect Informations In Accruals and Cash Flow About Future Earnings?. The Accounting Review. Vol.71(3):289 315

Schneemeier, Jan et, al. 2015. Firm Investment and Price Informativeness. working paper http; ssrn.com, diakses pada tanggal 14 Februari 2010
Subramanyam, et, al. 2013. Financial Statement Analysis. Ninth Edition, NewYork: Mc Graw Hill.

Subramanyam, K. R. 1996. The Pricing of Discretionary Accruals. Journals of Accounting and Economics. Vol. 22: 249281

Sugiyono. 2013. Metode Penelitian Bisnis, Bandung: CV Alfabeta.

Suwardjono. 2005. Akuntansi Pengantar Proses Penciptaan Data Pendekatan Sistem, Edisi Ketiga, Yogyakarta: BPFE Yogyakarta

Watts., Zimmerman. 1986. Positive Accounting Theory, University of Rochester, New Jersy: Prentice Hall

White, Sondhi dan Fried (1998) C. E. White. 1970. Discretionary Accounting Decisions and Income Normalization. Journal of Accounting Research. pp. 260 73.

Wolk, et, al., (2008), Accounting Theory Conseptual Issues in a Political and Economic Environtement, Seventh Edition, California:Sage Publications, Inc.

Zarowin \& Gelb. 2002. Corporate Disclosure Policy and the Informativeness of Stock Price, Review of Accounting Studies. Vol.7:33-52.

Zarowin, A. Paul., and Tucker, W. Jennifer. 2006. Does Income Smoothing Improve Earnings Informativeness. The Accounting Review, Vol. 81 (1): 251-270. 
Jurnal Ilmiah Econosains

Vol. 15 No. 2 Agustus 2017
E-ISSN: 2252-8490

http://doi.org/10.21009/econosains.015.2.5
Zarowin, A. Paul, 2002. Does Income Smoothing Improve Informativeness of Stock price?. The New York University, working paper http:ssrn.com, diakses pada 14 Februari 2010.
Zuhriya 2015. Perataan laba dan faktor-faktor yang mempengaruhi perusahaan consumer goods di Bursa Efek Indonesia . The Accounting Review, Vol. 81 (1): 251-270. 